\title{
OSALLISTUMISEN SIETÄMÄTÖN KEVEYS
}

Kun suomalainen aikuiskasvatus 1970-luvulla alkoi todenteolla profiloitua osaksi koulutusjärjestelmää ja kasvatustiedettä, niin sanotun aikuisväestön osallistuminen koulutukseen nousi teknokraattisen suunnitteluyhteiskunnan reformipolitiikan ja tutkimuksen keskiöön. Uraa uurtavia kartoituksia tehtiin eri aikuiskoulutusmuotoihin osallistujien määrästä ja laadusta sekä osallistumisen ja osallistumattomuuden syistä. Sittemmin kartoituksesta tuli viranomaistoimintaa ja sen kohde laajeni vapaan sivistystyön oppilaitoksista ja organisaatioista ammatilliseen aikuiskoulutukseen ja työpaikoilla tapahtuvaan koulutukseen. Aikuisoppilaitokset siirtyivätkin koulutuksen markkinoitumiskehityksen kärjessä osallistumiseen - 'osallistumistapahtumiin' - perustuvaan taloudelliseen ohjaukseen.

Suomalaisen aikuiskasvatuksen ja sen tutkimuksen itseymmärryksessä näyttää tapahtuneen täyskäännös verrattuna sen kehkeytymisen aikaan. Osallistamiseen tähtäävän kansanvalistuksen ajateltiin rakentavan kansallisvaltiota sekä kansallista taloutta ja sivistystä. EUSuomi on puolestaan innolla omaksunut ylikansallisen oppimisen hallinnan politiikan, joka on kirjattu muun muassa muistioon elin-

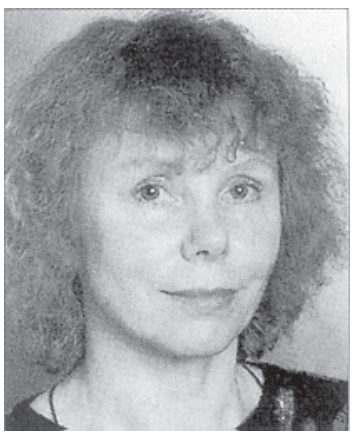

Anja Heikkinen ikäisestä oppimisesta (2000) ja kommunikeoihin elinikäisen oppimisen toteuttamisesta (2001) sekä kasvatuksesta ja koulutuksesta vuonna 2010 (2003). Kun Euroopan Unioniin luodaan uutta 'oppimisen kulttuuria', on kehitettävä yhtenäiset tavat arvottaa niin 'formaalia', 'non-formaalia' kuin ‘informaaliakin’ oppimista. Tämä edellyttää sitä, että mikä tahansa oppiminen voidaan tunnistaa, arvioida ja tunnustaa eli sertifioida. Angloamerikkalaisen maailman tapaan EU:n tulee pyrkiä yhtenäiseen, maantieteellisistä ja kulttuurisista esteistä riippumattomaan elinikäisen oppimisen ja sen kontrolloinnin järjestelmään. Tämä edellyttää ylikansallisia rakenteita ja standardeja oppimisen suunnitteluun, arviointiin ja kehittämiseen.

EU-eurooppalaisessa aikuiskasvatuksessa kasvun ja oppimisen diskurssit sisältävät räikeitä sisäisiä ristiriitoja. Yhtäällä voimistetaan tutkintoihin, todistuksiin ja opitun tunnustamiseen perustuvien järjestelmien perustavuutta, toisaalla korostetaan kokemuksellisen, hiljaisen ja paikallisissa käytänteissä uudistuvan oppimisen merkitystä innovaatioiden tuotantoon keskittyville yhteiskunnille ja talouksille. Koulutuspolitiikassa osallisuus (participation) tarkoittaa ensisijaisesti kelpaamista eurooppalaisille työmarkkinoille. Se ehdollistaa koulutuspoliittisten ohjelmien aktiivin kansalaisuuden, sosiaalisen tasa-arvon ja osallisuuden (social equality and inclusion) tavoitteet. Angloamerikkalaisessa maailmassa hallinnollisesti määriteltyyn ammatti- ja aikuiskoulutukseen osallistumisesta on tullut lähes ainoa ja eksklusiivinen osallistumisen - yhteiskunnallisen, poliittisen ja viime kädessä työmarkkinoille kelpaamisen - kriteeri. Myös EU-Euroopassa kansalaisuuden kriteeriksi on tullut oppijuus 
(learnership), joka määrittää osallisuuden etiikkaa ja politiikkaa. Elinikäinen oppiminen on avainasemassa työllistyvän ja osaavan, koulutetun ja sopeutuvan inhimillisen voimavaran hallintaan ja kehittämiseen (human resources management/development) Euroopassa. Oppimisen edistämisen politiikka on selkeästi alisteinen EU:n globaalia kilpailukykyä edistäville sosiaali-, työvoima- ja teknologiapolitiikoille.

Viimeisimmät EU:n ja Suomen (esimerkiksi KeSu 2003, Yliopistolain ja -asetuksen uudistus 2003) koulutuspoliittiset linjanvedot kohdistuvat oppimisen EU-tasoiseen modularisointiin ja harmonisointiin. Tarkoittaako tämä 'esteiden poistamista' yhteiseurooppalaisten opintojen, opintojaksojen ja oppimistulosten määrittelemisen tiellä? Eurooppalaisten ammatti-, aikuis- ja akateemisen koulutuksen järjestelmät ovat kuitenkin kehittyneet varsin erilaisiksi. Kansallisvaltion rakentamiseen kytkeytyvän aikuiskasvatuksen merkitystä arvioitiin sen perusteella, miten aikuiset aktivoituivat vaikuttamaan kansallisvaltioyhteiskunnan taloudelliseen, poliittiseen ja sivistykselliseen elämään. Oleellista oli korostaa osallistumisen ja osallistavan toiminnan vapautta niin poliittisesta, koulutuksellisesta kuin taloudellisesta hegemoniasta. Nyt kaikkien on esitettävä aktiivista kansalaisuutta osallistumalla elinikäisen oppimisen erilaisiin muotoihin, joiden määrittelyyn ja kontrolliin he itse, ja enimmäkseen oppimisen organisoijatkaan, eivät voi osallistua. Ovatko pyrkimykset yhteiseurooppalaisten ja vertailukelpoisten kasvatuksellisten arvojen jakamiseen ja laatujärjestelmien tuottamiseen realistisia ja/tai eettisesti perusteltuja?

Tutkijat ovat vasta alussa yrityksissään tunnistaa ja ymmärtää aikuiskasvatuksen ylikansallisten, totalitääristen ohjelmien kohteiden kokemuksia, joita näyttävät varsin yleisesti leimaavan turhautuneisuus ja vastarinta. Tämän Aikuiskasvatus-lehden kirjoitukset pohtivat eri lähtökohdista sitä, onko kansanvalistuksellisen, poliittista ja sosiaalista osallistumista edistävän aikuiskasvatuksen perinne sovitettavissa uuteen elinikäisen oppimisen hallinnan ylikansalliseen politiikkaan, joka edistää osallistumista inhimillisten voimavarojen kehittämiseen ja innovaatioiden tuottamiseen. Miten EU-eurooppalaisen koulutuspolitiikan kohteet kokevat heille suunnatut ohjelmat - kuten Noste-ohjelman - ja aikuisdidaktiikassa vallitseviksi tulleet oppijamielikuvat? Onko kokemusten näkyväksi tekemisellä mitään seurauksia aikuiskasvatuksen kehittämiselle ja osallistumista koskevan tutkimuksen tulevaisuudelle?

\section{Anja Heikkinen}

